\title{
Colocalization of Aluminum and Iron in Nuclei of Nerve Cells in Brains of Patients with Alzheimer's Disease
}

\author{
Sakae Yumoto $^{\mathrm{a}, *}$, Shigeo Kakimi ${ }^{\mathrm{b}}$ and Akira Ishikawa ${ }^{\mathrm{c}}$ \\ ${ }^{a}$ Yumoto Institute of Neurology, Kawadacho, Shinjuku-ku, Tokyo, Japan \\ ${ }^{\mathrm{b}}$ Department of Functional Morphology, Nihon University School of Medicine, Ohyaguchiuemachi, \\ Itabashi-ku, Tokyo, Japan \\ ${ }^{\mathrm{c}}$ Department of Physics, College of Humanities and Sciences, Nihon University, Sakurajousui, \\ Setagaya-ku, Tokyo, Japan
}

Accepted 23 July 2018

\begin{abstract}
Increasing evidence indicates that metal-induced oxidative stress plays a pivotal role in the pathogenesis of Alzheimer's disease (AD). Recently, the presence of 8-hydroxydeoxyguanosine, a biomarker of oxidative DNA damage, was demonstrated in nuclear DNA (nDNA) in the AD brain. Iron (Fe) is a pro-oxidant metal capable of generating hydroxyl radicals that can oxidize DNA, and aluminum $(\mathrm{Al})$ has been reported to facilitate Fe-mediated oxidation. In the present study, we examined the elements contained in the nuclei of nerve cells in AD brains using scanning electron microscopy coupled with energy-dispersive X-ray spectroscopy (SEM-EDS). Our results demonstrated that $\mathrm{Al}$ and $\mathrm{Fe}$ were colocalized in the nuclei of nerve cells in the $\mathrm{AD}$ brain. Within the nuclei, the highest levels of both $\mathrm{Al}$ and $\mathrm{Fe}$ were measured in the nucleolus. The SEM-EDS analysis also revealed the colocalization of $\mathrm{Al}$ and $\mathrm{Fe}$ in the heterochromatin and euchromatin in neuronal nuclei in the $\mathrm{AD}$ brain. Notably, the levels of $\mathrm{Al}$ and $\mathrm{Fe}$ in the nucleus of nerve cells in the $\mathrm{AD}$ brain were markedly higher than those in age-matched control brains. We hypothesize that the colocalization of $\mathrm{Al}$ and $\mathrm{Fe}$ in the nucleus of nerve cells might induce oxidative damage to nDNA and concurrently inhibit the repair of oxidatively damaged nDNA. An imbalance caused by the increase in DNA damage and the decrease in DNA repair activities might lead to the accumulation of unrepaired damaged DNA, eventually causing neurodegeneration and the development of AD.
\end{abstract}

Keywords: Aluminum, Alzheimer's disease, DNA damage, electron microscopy, energy-dispersive X-ray spectroscopy, iron, Fenton reaction, neurodegeneration, oxidative stress

\section{INTRODUCTION}

Alzheimer's disease (sporadic Alzheimer's disease, senile dementia of the Alzheimer type, AD) is an age-related neurodegenerative disease characterized by the accumulation of senile plaques and neurofibrillary tangles [1-4]. The incidence of AD is 14 -fold higher among people older than 85 years

\footnotetext{
${ }^{*}$ Correspondence to: Sakae Yumoto, MD, PhD, Yumoto Institute of Neurology, Kawadacho 6-11, Shinjuku-ku, Tokyo 162-0054, Japan. Tel.: +81 33341 3406; E-mail: yumoto-s @ viola.ocn.ne.jp.
}

than among people between 65 and 69 years of age, and $\mathrm{AD}$ affects as much as $47 \%$ of people over 85 years of age [5, 6]. Aging is the biggest risk factor for the development and progression of $\mathrm{AD}$ $[7,8]$.

The etiology of $\mathrm{AD}$ remains to be clarified, but growing lines of evidence indicate that metalinduced oxidative stress plays a pivotal role in $\mathrm{AD}$ pathogenesis [9-11]. Oxidized products of various biomolecules, including nucleic acids, proteins, lipids, and carbohydrates, were found to be markedly increased in the brains of elderly people 
and patients with $\mathrm{AD}$ [11-13]. Moreover, iron (Fe) levels were increased substantially in aged and $\mathrm{AD}$ brains [14, 15]. Excessive Fe accumulation has also been reported in neurodegenerative diseases such as Parkinson's disease, Huntington's disease, and amyotrophic lateral sclerosis [16-18]. Fe is essential for maintaining the function of the central nervous system; however, it is also a transition metal capable of generating, through the Fenton reaction, hydroxyl radicals $(\mathrm{OH} \bullet)$, which cause severe oxidative damage to biomolecules such as DNA, RNA, proteins, and lipids [10]. Copper $(\mathrm{Cu})$ is also a transition metal that can generate hydroxyl radicals [19], but $\mathrm{Cu}$ levels in the AD brain were found to decrease markedly with AD progression [20, 21]. Castellani et al. [10] and Honda et al. [22] have reported that hydroxyl radicals are mainly generated by the $\mathrm{Fe}$-mediated Fenton reaction in the $\mathrm{AD}$ brain.

An intriguing finding is that $\mathrm{Fe}$-mediated oxidation is facilitated, both in vitro and in vivo, by aluminum (Al), although $\mathrm{Al}$ itself is a non-redox-active metal [23-26]. Al cannot oxidize phospholipid liposomes by itself, but can accelerate Fe-induced peroxidation of these liposomes several fold [27, 28]. Moreover, $\mathrm{Al}$ administration to experimental animals is known to cause oxidative damage to nucleic acids, proteins, and lipids in the brain [29, 30]. Al has also been reported to potentiate $\mathrm{Fe}$-mediated oxidative stress in cultured neurons [31, 32]. Notably, increased Al levels have been reported in the aged brain and in brains of patients with AD [33-35]. In addition, Virk and Eslick have reported that $\mathrm{Al}$ levels in the $\mathrm{AD}$ brain were significantly higher than those in the agematched control brain [36].

Recently, the presence of 8-hydroxydeoxyguanosine, which is a biomarker of oxidative DNA damage, has been demonstrated in nuclear DNA (nDNA) in brains of patients with AD [37-39]. Because nDNA plays a critical role in the cell, oxidative damage to nDNA might represent one of the most important factors in neuronal degeneration and $\mathrm{AD}$ pathogenesis. DNA is a stable compound: therefore, reactive oxygen species (ROS) such as hydrogen peroxide or superoxide anion radicals cannot, by themselves, readily oxidize DNA [40, 41]. In contrast, hydroxyl radicals comprise the most potent ROS in the cell. These radicals can not only directly oxidize DNA but also alter gene sequences by oxidizing the proteins that bind to DNA [38, 41-44]. Prestwich et al. reported that when DNA-bound proteins were oxidized to form amino acid peroxides, the peroxides proceeded to cleave the DNA backbone by introducing single-strand breaks in the DNA [45, 46]. Furthermore, Moreira et al. have reported that hydroxyl radicals play a major role in DNA oxidation in the AD brain [11]. The halflives of hydroxyl radicals have been reported to be as short as $10^{-9} \mathrm{~s}(1 \mathrm{~ns})[47,48]$. Therefore, in order to oxidize nDNA, the Fe that catalyzes the generation of hydroxyl radicals through the Fenton reaction must either bind directly to nDNA, or to the histone proteins that closely bind nDNA [49-52].

To facilitate Fe-mediated oxidative reactions with nDNA, Al must be closely colocalized with Fe. However, the colocalization of $\mathrm{Fe}$ and $\mathrm{Al}$ in the nuclei of brain cells, particularly in the nuclei of nerve cells, remains to be clearly demonstrated in the AD brain. Honda et al. found that $\mathrm{Fe}$ was distributed homogenously in the nuclei of nerve cells in the AD brain when examined using histochemistry [53]. In contrast, Quintana et al. carried out analytical electron microscopy experiments and reported that Fe was not present in the nuclei of nerve cells in the AD brain, but was instead present at high concentrations in the nuclei of oligodendrocytes [54]. Furthermore, Connor et al. failed to detect $\mathrm{Fe}$ in the nuclei of nerve cells in the AD brain using histochemistry $[55,56]$.

$\mathrm{Al}$ has been reported to accumulate in the nuclei of nerve cells in the AD brain [57-62]. Walton reported $\mathrm{Al}$ accumulation in the nuclei of nerve cells in the AD brain using histochemistry [58]. We have also reported the presence of $\mathrm{Al}$ in isolated cell nuclei from $\mathrm{AD}$ brains using particle-induced X-ray emission (PIXE) analysis, microprobe PIXE analysis [59], and secondary ion mass spectrometry analysis [60]. Moreover, we have demonstrated $\mathrm{Al}$ accumulation in the nuclei of nerve cells in frozen thin sections from AD brains using transmission electron microscopy (TEM) coupled with energy-dispersive X-ray spectroscopy (EDS) [61, 62]. However, the localization of Fe in biological samples cannot be demonstrated using TEM-EDS analysis due to the high peak of the $\mathrm{Fe}$ spectrum that emerges from the components of the transmission electron microscope in TEM-EDS measurements [63].

In the current study, we examined the colocalization of $\mathrm{Fe}$ and $\mathrm{Al}$ in the nuclei of nerve cells in the AD brain using scanning electron microscopy (SEM) coupled with EDS (SEM-EDS). SEM-EDS analysis allows the concurrent imaging of subcellular structures with high spatial resolution and detection of small quantities of both $\mathrm{Al}$ and $\mathrm{Fe}$ contained in the same subcellular structures. 


\section{MATERIALS AND METHODS}

\section{Chemicals}

Potassium dichromate, ammonium molybdate, HEPES, ethanol, and propylene oxide were purchased from Wako Pure Chemical Industries, Ltd. (Osaka, Japan). Epon, 25\% glutaraldehyde, 20\% formaldehyde, carbon rods, and $\mathrm{Cu}$ mesh were obtained from Nisshin EM Co. Ltd. (Tokyo, Japan). $\mathrm{Al}$ distearate and ferric stearate were purchased from Soekawa Chemical Co., Ltd. (Tokyo, Japan) to prepare the standard samples for $\mathrm{Al}$ and $\mathrm{Fe}$, respectively. All buffers, fixatives, and staining solutions were prepared with Milli-Q water (Milli-Q Plus System, Millipore, Mississauga, ON, Canada).

\section{PIXE analysis of chemicals}

To ensure accurate measurements of $\mathrm{Al}$ and $\mathrm{Fe}$ in the samples using EDS analysis, it is critical to exclude contamination by exogenous $\mathrm{Al}$ and $\mathrm{Fe}$, and to rule out the presence of elements featuring energy levels that result in characteristic X-rays similar to those of Al K $\alpha$ (1.487 keV) and/or Fe K $\alpha(6.404 \mathrm{keV})$ [64]. PIXE analysis can be used to detect both $\mathrm{Al}$ and Fe with high sensitivity and concurrently demonstrate the presence of elements with energy levels that result in characteristic X-rays similar to those of $\mathrm{Al} \mathrm{K} \alpha$ and $\mathrm{Fe} \mathrm{K} \alpha$ [65]. All chemicals used for the preparation of the samples for SEM-EDS analyses were examined using PIXE analysis, as reported previously [63]. PIXE analysis was performed at an accelerating voltage of $3 \mathrm{MeV}$ using a tandem accelerator at the Micro Analysis Laboratory of Tokyo University [63].

\section{Standard samples for SEM-EDS analysis}

\section{Standard samples of Al (Al-Epon mixtures and Epon)}

In order to measure the $\mathrm{Al}$ levels in the brain samples, Al-standard samples were prepared. Al distearate was mixed with Epon to homogeneity and used to prepare Al-standard samples (Al-Epon mixtures) containing 100, 75, 50, 37.5, 25, and $12.5 \mathrm{ppm}$ Al. Al-Epon mixtures and Epon were hardened in an oven maintained at $60^{\circ} \mathrm{C}$, as reported previously [63]. Semi-thin sections (0.4- $\mu \mathrm{m}$ thick) of Epon and Al-Epon mixtures were cut using an LKB Ultratome microtome equipped with a diamond knife [63]. These semi-thin sections were analyzed by SEMEDS to prepare the standard curve of Al levels

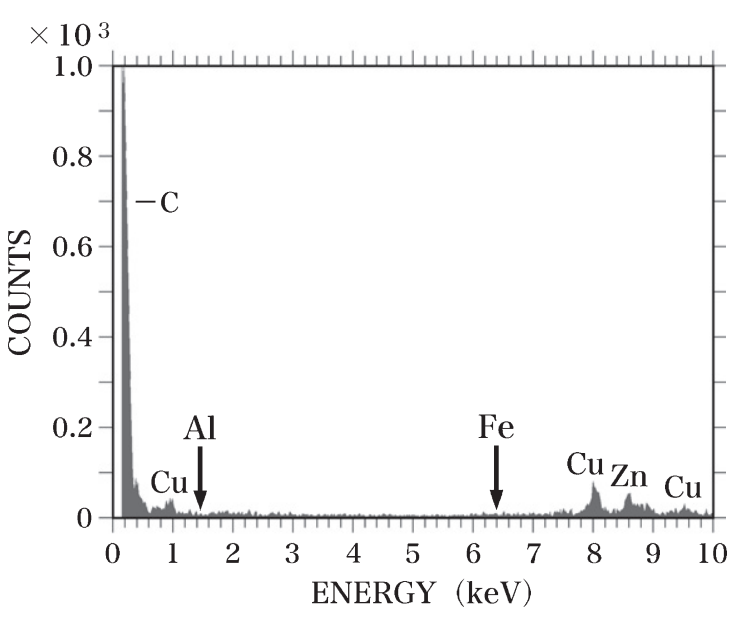

Fig. 1. EDS spectrum of the blank test. SEM-EDS analysis was performed without placing samples on the sample holder. No Al or $\mathrm{Fe}$ (arrows) was detected. The $\mathrm{C}$ peak appears to be derived from the sample holder made of carbon. The $\mathrm{Cu}$ and $\mathrm{Zn}$ peaks are considered to originate from the components of the electron microscope.

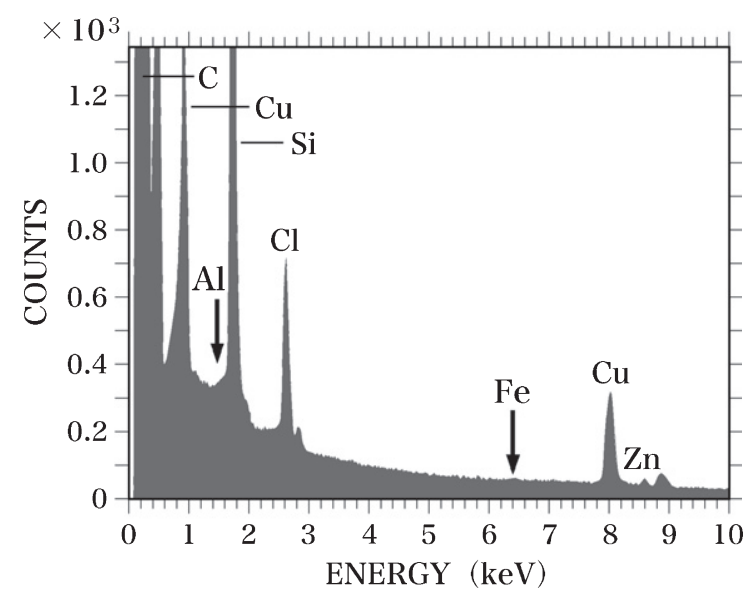

Fig. 2. EDS spectrum of an Epon section. A semi-thin section (0.4- $\mu \mathrm{m}$ thick) of Epon was analyzed using EDS. No $\mathrm{Al}$ or Fe (arrows) was detected in the section. The Si peak is considered to be generated from contamination by oil vapor evaporated from the vacuum pump oil. The $\mathrm{Cl}$ peak was considered to originate from the Epon itself.

(Fig. 3). The peak of $\mathrm{Al} \mathrm{K \alpha}(1.49 \mathrm{keV})$ and the background at $1.49 \mathrm{keV}$ were measured to determine the value of peak-to-background ratio (P-B/B). The $\mathrm{Al}$ standard curve was used to estimate the Al level in the brain sample by comparing the peak-to-background ratio of each brain sample with that of the standard curve. The standard curve was obtained by using the least squares method. 


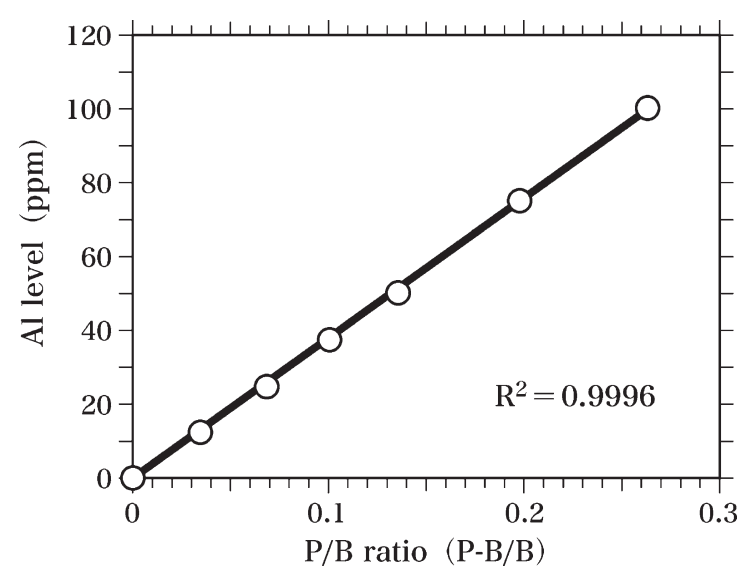

Fig. 3. Standard curve of Al. The standard curve of Al levels was prepare by SEM-EDS analysis using semi-thin sections $(0.4-\mu \mathrm{m}$ thick) of Epon and Al-Epon mixtures containing 100, 75, 50, 37.5, 25 , and $12.5 \mathrm{ppm} \mathrm{Al}$. The $\mathrm{Al}$ standard curve was used to calculate Al levels in brain samples by comparing the peak-to-background ratio $(\mathrm{P}-\mathrm{B} / \mathrm{B})$ of each sample with that of the standard curve. The standard curve was obtained using the least squares method.

\section{Standard samples of $\mathrm{Fe}$ (Fe-Epon mixtures and Epon)}

Fe-standard samples were prepared for measurements of $\mathrm{Fe}$ levels in the brain samples. Ferric stearate was mixed with Epon to homogeneity and used to prepare Fe-standard samples (Fe-Epon mixtures) containing 1600, 1200, 800, 600, 400, 200, and $100 \mathrm{ppm}$ Fe. Fe-Epon mixtures and Epon were hardened at $60^{\circ} \mathrm{C}$. Semi-thin sections $(0.4-\mu \mathrm{m}$ thick $)$ of Fe-standard samples and Epon were cut using an LKB Ultratome microtome equipped with a diamond knife. These semi-thin sections were analyzed by SEM-EDS to prepare the standard curve of Fe levels (Fig. 4). The peak of $\mathrm{Fe} \mathrm{K} \alpha(6.40 \mathrm{keV})$ and the background at $6.40 \mathrm{keV}$ were measured to determine the value of peak-to-background ratio (P-B/B). The Fe standard curve was applied to calculate $\mathrm{Fe}$ levels in the brain sample by comparing the peakto-background ratio of each sample with that of the standard curve. The standard curve of Fe levels was obtained by using the least squares method.

\section{Preparation of brain samples for SEM-EDS analysis}

Brain samples were obtained from the Department of Pathology at the University of Tokyo, and the Department of Pathology at Nihon University School of Medicine, where the samples were classified based on pathology. In this study, we used samples from 5 patients with $\mathrm{AD}$ (age range: $76-85 \mathrm{y}$; mean age: $82 \mathrm{y}$ )

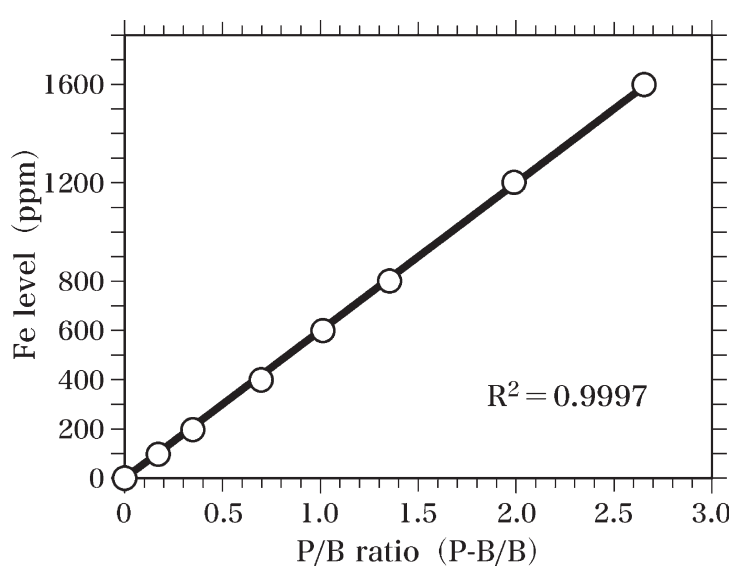

Fig. 4. Standard curve of Fe. The standard curve of Fe levels was made by SEM-EDS analysis using semi-thin sections $(0.4-\mu \mathrm{m}$ thick) of Epon and Fe-Epon mixtures containing 1600, 1200, 800, $600,400,200$, and $100 \mathrm{ppm} \mathrm{Fe}$. The Fe standard curve was used to estimate Fe levels in brain samples by comparing the peak-tobackground ratio $(\mathrm{P}-\mathrm{B} / \mathrm{B})$ of each sample with that of the standard curve. The standard curve was obtained using the least squares method.

and 5 age-matched controls without any neurological disorders (age range: $74-85 \mathrm{y}$; mean age: $81 \mathrm{y}$ ). This study was conducted in accordance with the 1975 Declaration of Helsinki on the ethical principles for medical research involving human subjects as stated by the World Medical Association.

Samples used for SEM-EDS analyses were prepared using a method reported previously, with minor changes [63]. Brain samples (hippocampus and temporal lobe) were removed at autopsy from the brains of patients with $\mathrm{AD}$ and age-matched controls using a clean stainless steel knife. After the brain tissues were transferred to a clean room, the cutting surface made at autopsy was cut off using a sharp, clean ceramic knife (Kyocera Corporation, Kyoto, Japan) and the arachnoid membrane was removed using a pair of ceramic tweezers (Kyocera Corporation). All autopsy instruments used in the present study were rinsed in $70 \%$ ethanol overnight, washed with ethanol, rinsed in Milli-Q water, dried, and stored in a clean box before use. Samples from the hippocampus and the cortex of the temporopolar area in the superior temporal gyrus (temporal cortex, Brodmann area 38) were collected from each patient for this study. The temporal cortex was used because the DNA in the temporal lobe has been reported to be the most oxidatively damaged in the AD brain [66]. The tissue samples were cut into small blocks, fixed with $3 \%$ glutaraldehyde and $2.5 \%$ paraformaldehyde in 0.1 M HEPES buffer ( $\mathrm{pH}$ 7.2) for $12 \mathrm{~h}$, washed with 
$10 \%$ sucrose in the same buffer for $1 \mathrm{~h}$, and postfixed with $3 \%$ glutaraldehyde and $2.5 \%$ potassium dichromate in 0.1 M HEPES buffer (pH 7.6) for $3 \mathrm{~h}$. Samples were dehydrated using an ascending series of ethanol, embedded into Epon using a clean plastic capsule with a cap, and hardened at $60^{\circ} \mathrm{C}$. Thirty to fifty Epon blocks were prepared from the brains of each subject.

Semi-thin sections $(0.4-\mu \mathrm{m}$ thick) were cut using an LKB Ultratome microtome equipped with a diamond knife, mounted on $\mathrm{Cu}$ mesh, washed with Milli-Q water several times, and dried in a clean desiccator. To avoid environmental contamination, all the processes for cutting and staining of semi-thin sections were carried out in a clean room.

Approximately, 80-120 sections were prepared from the hippocampus and temporal cortex from each patient. These semi-thin sections were stored in a clean desiccator and used as samples for SEM-EDS analysis.

In the present study, potassium dichromate was used instead of osmium (Os) tetroxide as a fixative for the brain samples. Os tetroxide is the standard fixative used to prepare biological samples for electron microscopy. However, the energy levels of the characteristic X-ray for $\mathrm{Al} \mathrm{K} \alpha(\mathrm{K} \alpha-1,1.48670 \mathrm{keV}$ and $\mathrm{K} \alpha-2,1.48627 \mathrm{keV})$ and those for Os $\mathrm{M} \xi(\mathrm{M} \xi$ $1,1.4919 \mathrm{keV}$ and $\mathrm{M} \xi-2,1.4831 \mathrm{keV})$ are too close for them to be distinguished using EDS analysis [63, 64]. The characteristic X-rays of chromium (Cr) or potassium do not possess energy levels close to those of either Al-K $\alpha$ or Fe-K $\alpha$ [64]. Therefore, we used potassium dichromate as a fixative to study the characteristic X-rays of $\mathrm{Al}-\mathrm{K} \alpha$ and $\mathrm{Fe}-\mathrm{K} \alpha$ using EDS analysis.

\section{Analysis of samples using SEM-EDS}

The EDS spectra of the standard samples and the brain samples were examined using an EX-64175 JMU X-ray microanalyzer (JEOL Ltd., Tokyo, Japan) combined with a JSM-7000F Type-A scanning electron microscope (JEOL Ltd.). Samples were placed on a sample holder made of carbon, and the evacuated sample chamber containing the sample holder was cooled using liquid nitrogen. The nuclei of nerve and glial cells were identified using SEM. A small spot $(0.2 \mu \mathrm{m}$ in diameter) in the samples was irradiated for 10 or $30 \mathrm{~min}$ with electron beams at an accelerating voltage of $15 \mathrm{keV}$, and the emitted X-rays were analyzed using the $\mathrm{X}$-ray microanalyzer.
Table 1

Summarized results of the EDS analysis on nerve cells in AD brains and age-matched control brains

\begin{tabular}{lcccc}
\hline \multicolumn{5}{c}{ Nerve Cells in AD Brains } \\
\hline Component of nerve cell & Al (ppm) & Fe (ppm) \\
& Mean \pm SD & n & Mean \pm SD & n \\
\hline Nucleolus & $48 \pm 9.0$ & 25 & $895 \pm 143$ & 25 \\
Heterochromatin & $24 \pm 3.7$ & 25 & $411 \pm 78$ & 25 \\
Euchromatin & $25 \pm 5.3$ & 25 & $313 \pm 54$ & 25 \\
Perinuclear Cytoplasm & not detected & 25 & $634 \pm 67$ & 25 \\
\hline \multicolumn{4}{c}{ Nerve Cells in Control Brains } \\
\hline Component of nerve cell & Al (ppm) & Fe (ppm) \\
& Mean \pm SD & n & Mean \pm SD & n \\
\hline Nucleolus & $21 \pm 4.1$ & 25 & $317 \pm 43$ & 25 \\
Heterochromatin & not detected & 25 & not detected & 25 \\
Euchromatin & not detected & 25 & not detected & 25 \\
Perinuclear Cytoplasm & not detected & 25 & $621 \pm 62$ & 25 \\
\hline
\end{tabular}

Table 1 shows the summarized results of the EDS analysis on nerve cells in $5 \mathrm{AD}$ brains and 5 control brains. For each major region of the nerve cell, 25 samples obtained by EDS analysis are shown in the Table. For the 25 samples, 5 samples were used from the analysis of each brain. We estimated the pairwise comparisons between the levels of $\mathrm{Al}$ and/or Fe for each major neuronal region in the AD brain and control brain by the Welch $t$-test method. SD, standard deviation; n, number of samples.

The level of $\mathrm{Al}$ in brain samples was estimated by comparing the peak-to-background ratio $(\mathrm{P}-\mathrm{B} / \mathrm{B})$ of each brain sample with that of the $\mathrm{Al}$ standard curve (Fig. 3). The level of Fe in brain samples was also determined by comparing the peak-to-background ratio $(\mathrm{P}-\mathrm{B} / \mathrm{B})$ of each brain sample with that of the Fe standard curve (Fig. 4). We performed the pairwise comparisons between the levels of $\mathrm{Al}$ and/or Fe for each major neuronal region in the $\mathrm{AD}$ brain and those in the control brain by the Welch's $t$-test method [67] (Table 1).

\section{RESULTS}

\section{PIXE analysis of chemicals used for sample preparation for SEM-EDS analysis}

PIXE analysis did not reveal the presence of $\mathrm{Al} \mathrm{K \alpha}$ or Fe $\mathrm{K} \alpha$ in the chemicals used to prepare the samples for SEM-EDS analysis. We also did not detect the presence of any element featuring energy levels with characteristic X-rays close to those of $\mathrm{Al}-\mathrm{K} \alpha$ or $\mathrm{Fe}$ $\mathrm{K} \alpha$ in the chemicals used.

\section{SEM-EDS analysis}

\section{Blank test}

When SEM-EDS analysis was performed without placing the samples on the sample holder, we 
observed peaks for carbon $(\mathrm{C}), \mathrm{Cu}$, and zinc $(\mathrm{Zn})$ (Fig. 1). No peaks for Al-K $\alpha$ or Fe-K $\alpha$ were detected. The $\mathrm{C}$ peak was considered to originate from the sample holder, which was made of carbon, and the peaks for $\mathrm{Cu}$ and $\mathrm{Zn}$ were due to the $\mathrm{Cu}$ and $\mathrm{Zn}$ used in the components of the electron microscope [63].

\section{Standard samples}

In the Epon semi-thin sections (0.4- $\mu \mathrm{m}$ thick), peaks for $\mathrm{C}$, silicon $(\mathrm{Si})$, chlorine $(\mathrm{Cl}), \mathrm{Cu}$, and $\mathrm{Zn}$ were detected using SEM-EDS analysis. We observed no $\mathrm{Al}$ or Fe peaks in these samples (Fig. 2). The detected $\mathrm{Cl}$ peak was considered to originate from the Epon itself, as a considerable amount of $\mathrm{Cl}$ was measured in Epon using TEM-EDS analysis $[63,68]$ and PIXE analysis [63]. We have previously reported that the Si peak observed in Epon sections using TEM-EDS analysis might result from the vacuum oil used for the electron microscope [63]. Si was not detected in Epon here using PIXE analysis. An Al-Ko peak was detected in sections of the AlEpon mixture (Al-standard sample), which contains $12.5 \mathrm{ppm} \mathrm{Al}$. When the $\mathrm{Al}$ concentration in the $\mathrm{Al}-$ Epon mixture was raised from 12.5 to $25,37.5,50$, 75 , or $100 \mathrm{ppm}$, the magnitudes of the Al-K $\alpha$ peaks increased correspondingly (Fig. 3).

Furthermore, an $\mathrm{Fe}-\mathrm{K} \alpha$ peak was detected in the sections of the Fe-Epon mixture (Fe-standard sample) containing $100 \mathrm{ppm}$ Fe. When the Fe concentration in the mixture was raised to $200,400,600,800,1200$, and $1600 \mathrm{ppm}$, the amplitudes of the $\mathrm{Fe}-\mathrm{K} \alpha$ peaks increased almost proportionally to the increase in $\mathrm{Fe}$ concentrations (Fig. 4).

\section{Brain samples}

\section{Nerve cells in $A D$ brains}

The SEM images in this study were produced by scanning the surface of semi-thin sections $(0.4-\mu \mathrm{m}$ thick) of brains with a focused beam of electrons. In the area where atoms were dense, the SEM images were bright, whereas the SEM image were dark in the area where atoms existed sparsely. In contrast, the TEM images have been known to be dark in regions with a high density of atoms and bright in regions with sparse atoms. Namely, the bright and dark image were reversed between SEM and TEM.

Figure 5 shows a SEM micrograph of a nerve cell in the temporal cortex of the AD brain taken at autopsy, and fixed with potassium dichromate. The nerve cell possessed a large nucleus in the center and two dendrites (Fig. 5, D) branched from the

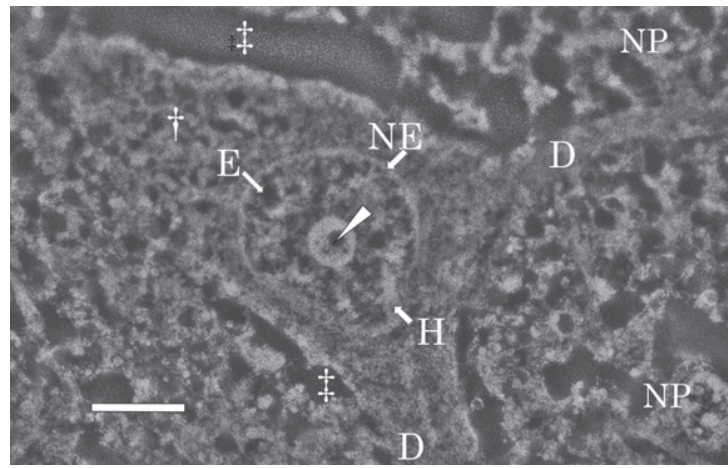

Fig. 5. SEM micrograph of a nerve cell in the temporal cortex of the AD brain. The SEM micrograph shows a nerve cell of the AD brain fixed with potassium dichromate and stained with ammonium molybdate. The nuclear envelope (NE) shows an intact shape. Intranuclear structures such as the nucleolus, heterochromatin $(\mathrm{H}$, bright region), and euchromatin (E, dark region) are well preserved. In the center of the nucleolus, pars amorpha (arrowhead) is clearly observed. Two dendrites (D) branches from the cytoplasm (dagger) of the nerve cell. Due to postmortem changes, the extracellular space (double dagger) is enlarged. NP, neuropil. Scale bar, $2 \mu \mathrm{m}$.

cytoplasm (Fig. 5, dagger) of the nerve cell. Neurons were surrounded by neuropil (NP), which consisted mainly of unmyelinated axons, dendrite and glial cell processes [69, 70]. The extracellular space (double dagger) was enlarged due to postmortem changes in the brain.

The nuclear envelope (Fig. 5, NE) was intact, with no breakage observed. The intranuclear structures such as the nucleolus, heterochromatin ( $\mathrm{H}$ in Fig. 5, bright region), and euchromatin (E in Fig. 5, dark region) were preserved well despite using an autopsy brain. The nucleolus was large, well developed, and contained small circular dark regions, pars amorpha (Fig. 5, arrowhead), in the center. The morphological features of the intranuclear structures found in sections fixed with potassium dichromate and observed by SEM in this study were essentially the same as those previously observed by TEM after fixation with Os tetroxide [69, 70].

Figure 6 shows SEM-EDS analysis on the nucleus of the nerve cell in the AD brain exhibited in Fig. 5. It is well known that nDNA is localized exclusively in the nucleus [39], but not located in the cytoplasm, or in nerve processes such as axons or dendrites. Therefore, the SEM-EDS analysis in this study focused on the localization of $\mathrm{Al}$ and $\mathrm{Fe}$ in the nucleus of nerve cells in order to investigate the mechanism of nDNA oxidation and to clarify the pathogenesis of AD. Additionally, the perinuclear cytoplasm and the extracellular space were also analyzed by 

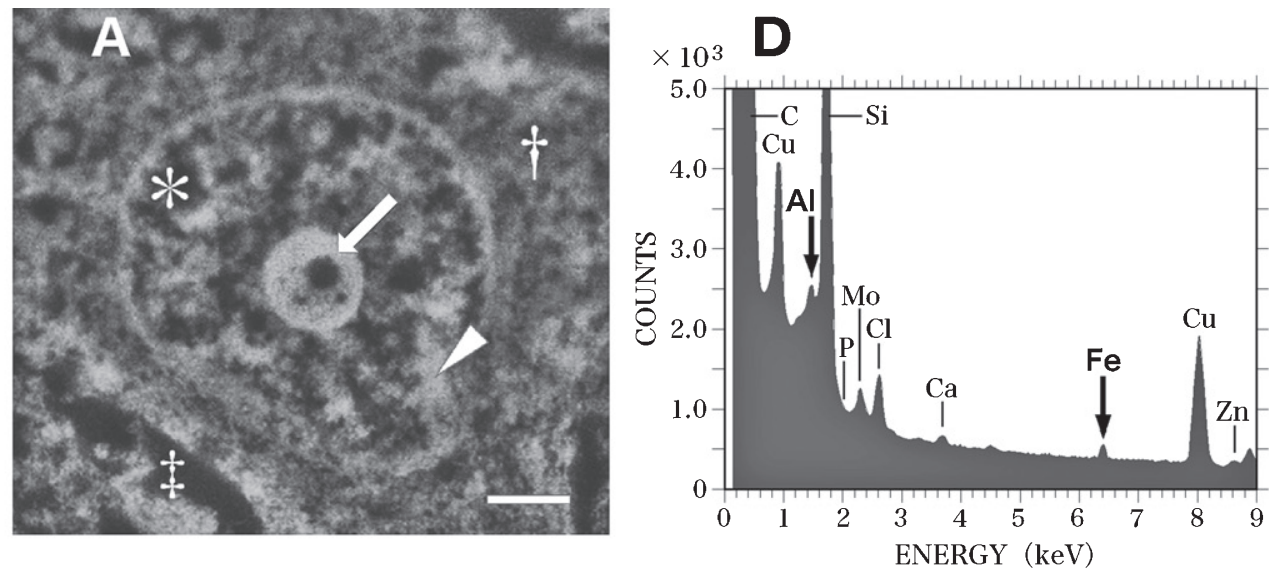

B
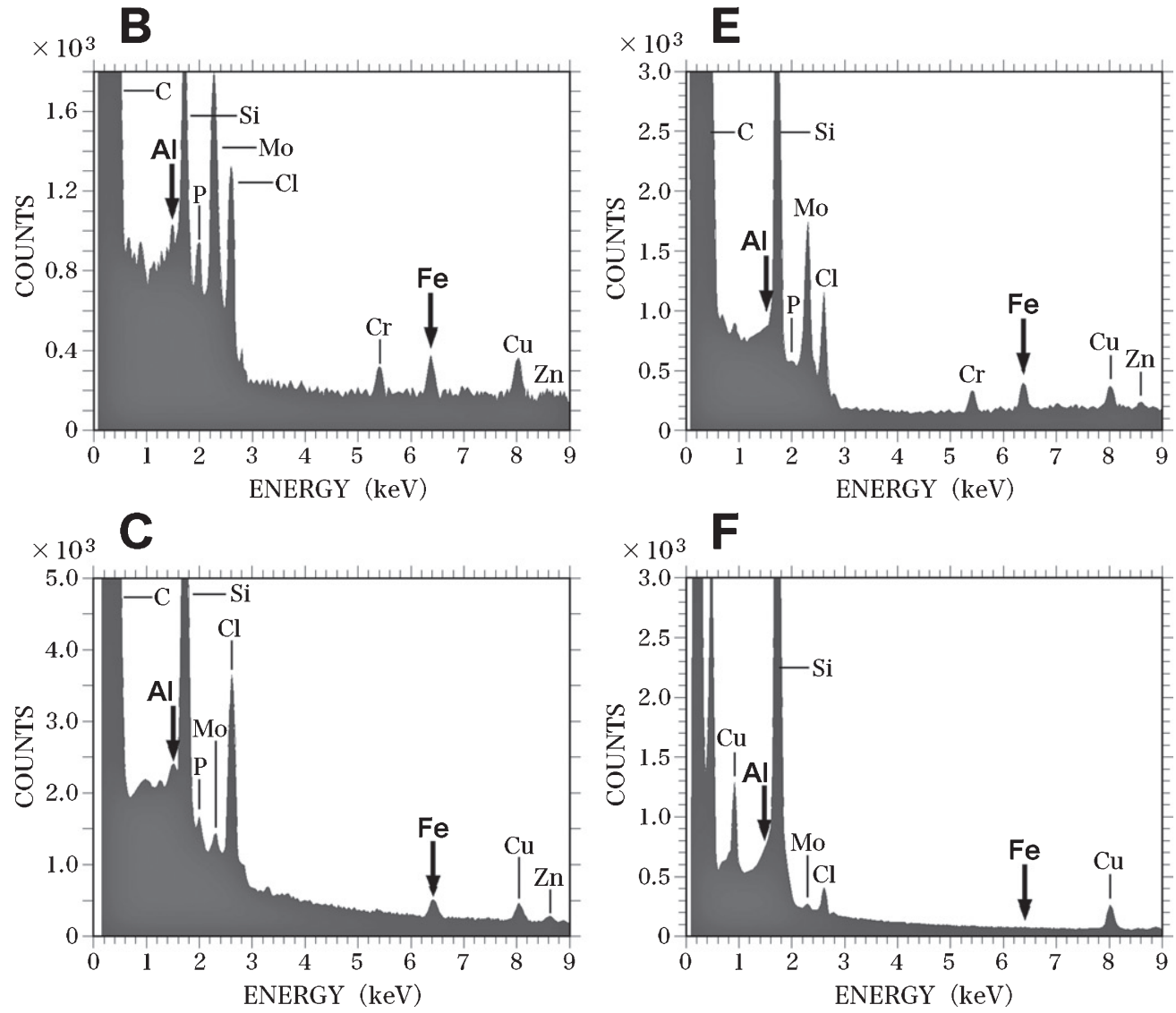

Fig. 6. SEM-EDS analysis of the nucleus of the nerve cell in the AD brain shown in Fig. 5. A) SEM image of the nucleus of the nerve cell in the AD brain shown in Fig. 5. SEM examination shows a well-developed, large nucleolus (arrow), heterochromatin (arrowhead), and euchromatin (asterisk) in the nucleus. Dagger shows the perinuclear cytoplasm. Double dagger indicates the extracellular space. Scale bar, $1 \mu \mathrm{m}$. B) EDS spectrum of the nucleolus (A, arrow) of the nerve cell in the AD brain. A small region ( $0.2 \mu \mathrm{m}$ in diameter) of the nucleolus in the nerve cell was examined using EDS. Elevated peaks for Al and Fe (arrows) are demonstrated. C) EDS spectrum of the heterochromatin (A, arrowhead) of the nerve cell in the AD brain. $\mathrm{Al}$ and Fe peaks (arrows) are detected in the heterochromatin. D) EDS spectrum of the euchromatin (A, asterisk) of the nerve cell in the AD brain. $\mathrm{Al}$ and Fe peaks (arrows) are detected in the euchromatin. The peaks for both $\mathrm{Al}$ and $\mathrm{Fe}$ measured in the heterochromatin and euchromatin are markedly lower than those measured in the nucleolus. E) EDS spectrum in the perinuclear cytoplasm (A, dagger) of the nerve cell in the $\mathrm{AD}$ brain. The elevated Fe peak is demonstrated in the perinuclear region of the cytoplasm. In contrast, no Al peak is detected. F) EDS spectrum in the extracellular space (A, double dagger) in the AD brain. No Al or $\mathrm{Fe}$ can be detected in the extracellular space. 
SEM-EDS as controls of the analysis on the intranuclear structures.

When a small region $(0.2 \mu \mathrm{m}$ in diameter $)$ of the nucleolus (Fig. 6A, arrow) was analyzed using EDS, $\mathrm{Al}$ and $\mathrm{Fe}$ were found to be clearly colocalized (Fig. 6B, arrows). Peaks for phosphorus (P), molybdenum (Mo), and $\mathrm{Cr}$ were also detected in the nucleolus (Fig. 6B). The Mo peak was considered to originate from the staining of sections with ammonium molybdate, and the $\mathrm{Cr}$ peak was thought to be due to the fixation of brain samples with potassium dichromate. The $\mathrm{P}$ peak was considered to represent the phosphorus in the nucleic acids and histone proteins contained in the nucleolus [63]. The EDS analysis also demonstrated the colocalization of $\mathrm{Al}$ and $\mathrm{Fe}$ in the heterochromatin (Fig. 6C) and euchromatin (Fig. 6D) of nerve cells. However, the peaks of both $\mathrm{Al}$ and $\mathrm{Fe}$ measured in the heterochromatin and euchromatin were markedly lower than those in the nucleolus.

In the perinuclear region of the cytoplasm (Fig. 6A, dagger), an elevated Fe peak was observed, while no Al peak could be detected using EDS (Fig. 6E). In this study, neurofibrillary tangles in the cytoplasm of nerve cells in the AD brain were not examined using EDS, because tangles have been previously reported to contain high levels of $\mathrm{Al}$ [71] and $\mathrm{Fe}$ [72]. In the extracellular space (Fig. 6A, double dagger) surrounding nerve cells, no $\mathrm{Al}$ or $\mathrm{Fe}$ was detected using EDS (Fig. 6F). The contamination of these nerve cells with environmental $\mathrm{Al}$ or Fe can thus be ruled out. The SEM-EDS analyses revealed no significant differences between the nerve cells in the temporal cortex and those in the hippocampus in the AD brain.

\section{Nerve cells in control brains}

Figure 7 shows a SEM micrograph of a nerve cell in the hippocampus of the control brain taken at autopsy, and fixed with potassium dichromate. A large nucleus was located in the center of the nerve cell. A dendrite (D in Fig. 7) branched from the cytoplasm (dagger in Fig. 7). The extracellular space (double dagger in Fig. 7) became enlarged due to postmortem changes. The nuclear envelope (NE) retained its intact structure without breakage. The intranuclear structures such as the nucleolus, heterochromatin $(\mathrm{H}$, bright region), and euchromatin (E, dark region) were well preserved.

Figure 8 shows SEM-EDS analysis on the nerve cell in the control brain exhibited in Fig. 7. Figure 8A presents a SEM image of the nucleus of the nerve cell shown in Fig. 7. Intranuclear structures such as the

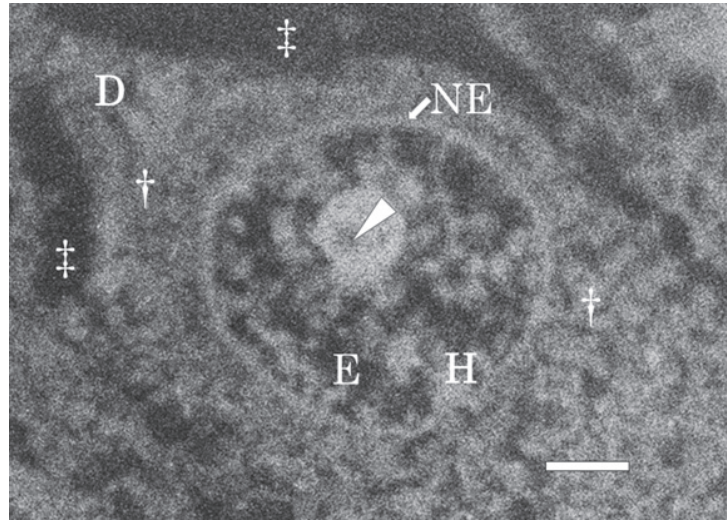

Fig. 7. SEM micrograph of a nerve cell in the hippocampus of the control brain. The SEM micrograph exhibits a nerve cell of the control brain fixed with potassium dichromate and stained with ammonium molybdate. The nuclear envelope (NE) retains an intact structure and the intranuclear structures such as the nucleolus, heterochromatin ( $\mathrm{H}$, bright region), and euchromatin (E, dark region) are well preserved. A dendrite (D) branches from the cytoplasm (dagger). An arrow shows pars amorpha in the nucleolus. The extracellular space (double dagger) is enlarged due to postmortem changes. Scale bar, $1 \mu \mathrm{m}$.

nucleolus (Fig. 8A, arrow), heterochromatin (Fig. 8A, arrowhead), and euchromatin (Fig. 8A, asterisk) were clearly observed.

EDS analysis proved peaks for both $\mathrm{Al}$ and $\mathrm{Fe}$ (Fig. 8B, arrows) in the nucleolus. However, the $\mathrm{Al}$ and $\mathrm{Fe}$ peaks in the nucleoli of nerve cells in the control brain were markedly lower than those in the $\mathrm{AD}$ brain. No $\mathrm{Al}$ or Fe could be detected in the heterochromatin or the euchromatin of nerve cells in the control brain (Fig. 8C and Fig. 8D, respectively. In the perinuclear region of the cytoplasm of nerve cells (Fig. 8A, dagger), a large peak for Fe was detected, although no $\mathrm{Al}$ was found here (Fig. 8E). In the extracellular space (Fig. 8A, double dagger) surrounding nerve cells, no Al or Fe could be detected using EDS (Fig. 8F). Moreover, SEM-EDS analyses revealed no significant differences between nerve cells in the temporal cortex and those in the hippocampus of the control brain.

Table 1 summarizes the results of the EDS analysis of nerve cells in the $\mathrm{AD}$ and control brains. The colocalization of $\mathrm{Al}$ and $\mathrm{Fe}$ was demonstrated in the nucleolus, heterochromatin, and euchromatin in the nuclei of nerve cells in the AD brain. Statistical analysis by Welch's $t$-test method showed that the levels of $\mathrm{Al}$ and $\mathrm{Fe}$ in the nucleus of nerve cells in the $\mathrm{AD}$ brain were markedly higher than those in age-matched control brains ( $t$-test, $p<0.05$ ) [67]. The statistical analysis by Welch's $t$-test also revealed that 


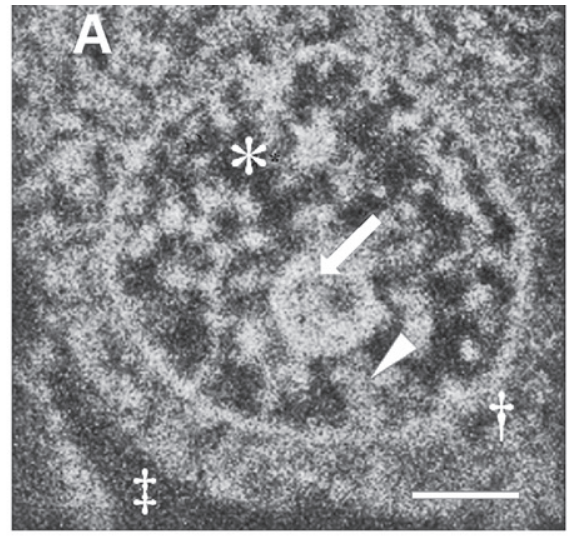

B
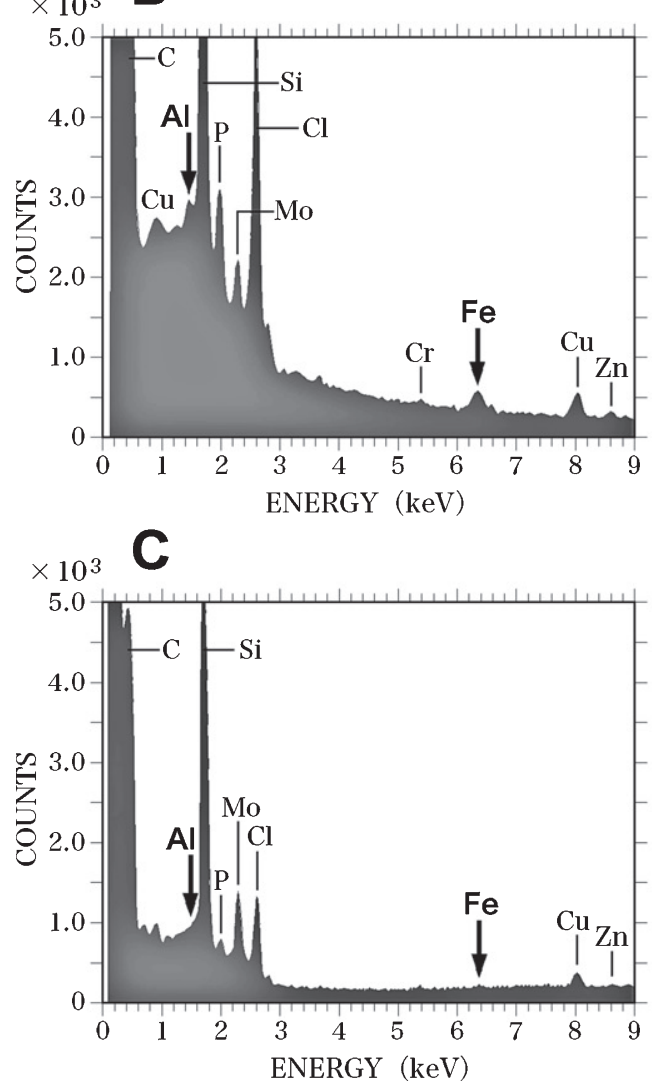

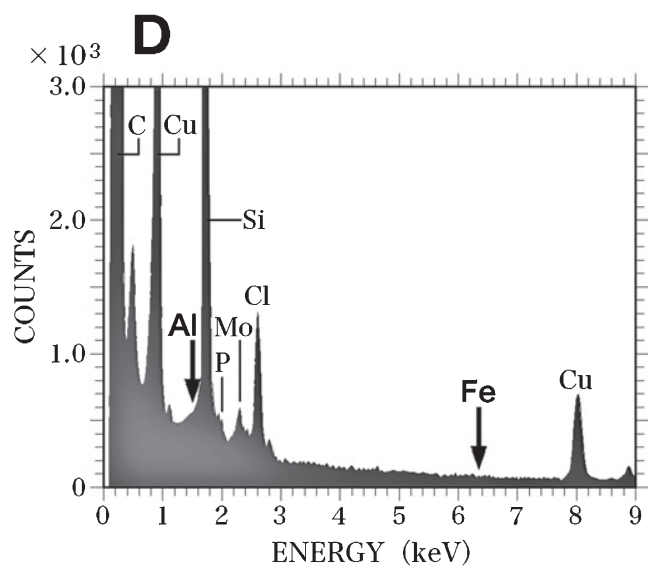

E
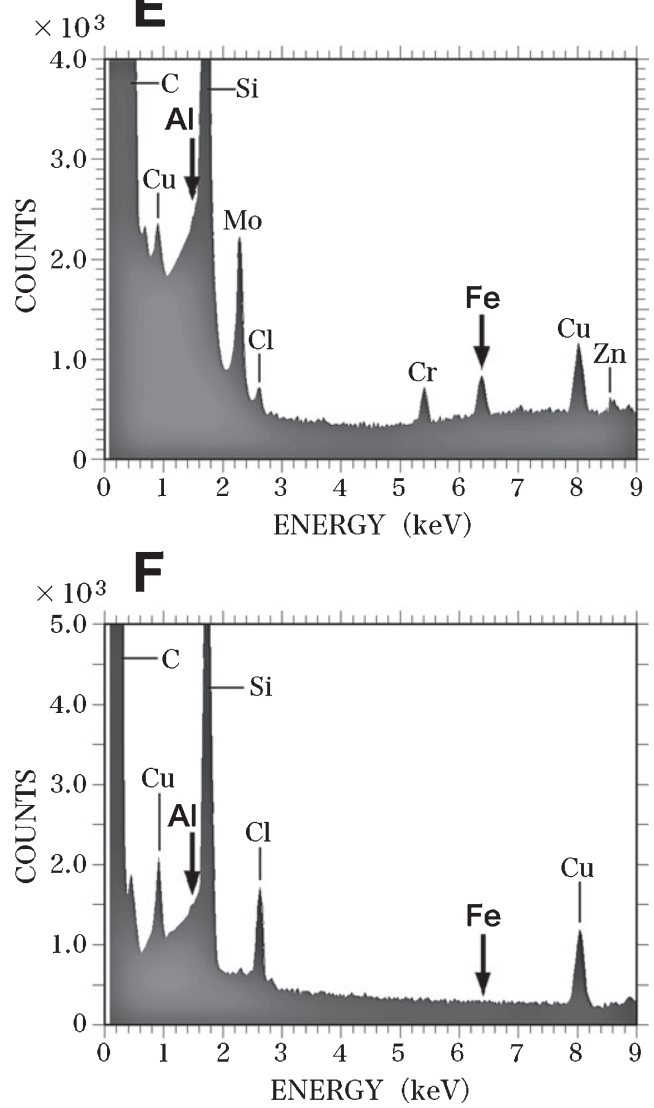

Fig. 8. SEM-EDS analysis of the nucleus of the nerve cell in the control brain exhibited in Fig. 7. A) SEM image of the nucleus of the nerve cell in the control brain shown in Fig. 7. SEM image shows the nucleolus (arrow), heterochromatin (arrowhead) and euchromatin (asterisk) in the nucleus. Dagger shows the perinuclear cytoplasm. Double dagger indicates the extracellular space. Scale bar, $1 \mu \mathrm{m}$. B) EDS spectrum of the nucleolus (A, arrow) of the nerve cell in the control brain. Arrows indicate the sites for Al $\mathrm{K} \alpha(1.487 \mathrm{keV})$ and Fe K $\alpha$ $(6.404 \mathrm{keV})$, respectively. $\mathrm{Al}$ and Fe peaks (arrows) are detected in the nucleolus. However, these $\mathrm{Al}$ and $\mathrm{Fe}$ peaks of the nucleolus in the control brain are significantly lower than those measured in the AD brain C) EDS spectrum of the heterochromatin (A, arrowhead) in the nerve cell of the control brain. No $\mathrm{Al}$ or Fe can be detected in the heterochromatin in the control brain. D) EDS spectrum of the euchromatin (A, asterisk) in the nerve cell in the control brain. No $\mathrm{Al}$ or $\mathrm{Fe}$ can be detected in the euchromatin in the control brain. E) EDS spectrum in the perinuclear cytoplasm (A, dagger) in the nerve cell in the control brain. The elevated peak for Fe is demonstrated in the perinuclear cytoplasm. In contrast, no Al peak is detected. F) EDS spectrum in the extracellular space (A, double dagger) in the control brain. No Al or Fe can be detected in the extracellular space in the control brain. 
both $\mathrm{Al}$ and $\mathrm{Fe}$ levels in the nucleolus were the highest within the nuclei of nerve cells in the AD brain. On the other hand, the levels of $\mathrm{Fe}$ in the perinuclear cytoplasm were almost similar levels in the AD and control brain.

\section{DISCUSSION}

Here we demonstrated the colocalization of $\mathrm{Al}$ and $\mathrm{Fe}$ in the nuclei of nerve cells in the AD brain using SEM-EDS analysis. In neuronal nuclei in the AD brain, the highest levels of both $\mathrm{Al}$ and $\mathrm{Fe}$ were measured in the nucleoli. $\mathrm{Al}$ and $\mathrm{Fe}$ were colocalized in the heterochromatin and euchromatin in these nuclei. Notably, Fe and Al levels in the nuclei of nerve cells were significantly higher in AD brains than in agematched control brains. In contrast, similar levels of $\mathrm{Fe}$ were measured in the perinuclear cytoplasm of nerve cells in $\mathrm{AD}$ and control brains. It is likely that the overloading of Fe due to Fe dyshomeostasis [73, 74] in nerve cells in the AD brain may lead to the accumulation of excess $\mathrm{Fe}$ in the nucleus of nerve cells.

Intranuclear DNA-containing structures, such as the nucleolus, heterochromatin, and euchromatin, are composed of assemblies of chromatin fibers (chromatin). Each chromatin fiber mainly consists of nDNA and histone proteins, which bind firmly to each other [50-52]. We have previously reported that when $\mathrm{Al}-26$, which is a radioisotope of $\mathrm{Al}$, was intraperitoneally injected into rats, $90 \%$ of the Al-26 incorporated into the isolated brain-cell nuclei was bound to the chromatin fraction [75]. Al has been reported to exhibit high affinity for phosphate groups [76-78], and Martin has reported that phosphorylated histone proteins represent a crucial Al-binding site in chromatin [79]. Lukiw et al. have reported that $\mathrm{Al}$ binds to $\mathrm{H} 1$ linker histone proteins, which bind to linker DNA [80, 81]. Moreover, Llorente et al. have demonstrated the binding of $\mathrm{Al}$ to $\mathrm{n}$ DNA contained within chromatin using fluorescence microscopy [82].

$\mathrm{Fe}^{3+}$ also exhibits high affinity for DNA [41] and phosphorylated proteins [83]. In the AD brain, Fe was demonstrated to bind to DNA [83, 84]. This binding was reported to be due to the dysregulation of $\mathrm{Fe}$ homeostasis associated with $\mathrm{AD}$ [73, $74,85,86] . \mathrm{Fe}^{3+}$ was shown to selectively bind to isolated phosphorylated proteins in vitro [83, 87]. Yamamoto et al. have reported that $\mathrm{Fe}^{3+}$ selectively binds to phosphorylated tau proteins [88], which are the major components of paired helical filaments present in the AD brain [89]. Because $\mathrm{Fe}^{3+}$ displays robust phosphate-binding capacity [90] and can selectively bind to phosphorylated proteins $[83,87$, 88], phosphorylated histone proteins might represent Fe-binding sites in neuronal nuclei of AD brains. Therefore, we conclude that a considerable fraction of the $\mathrm{Al}$ and $\mathrm{Fe}$ contained in the nuclei of nerve cells in the $\mathrm{AD}$ brain might bind to nDNA and/or phosphorylated histone proteins, and that these two metals might be colocalized in close proximity to each other in chromatin in neuronal nuclei in the AD brain.

DNA is oxidized by the hydroxyl radicals generated via the Fenton reaction in the presence of $\mathrm{Fe}$ (Fe(II)) and hydrogen peroxide [41, 42, 91]. However, during the Fenton reaction, $\mathrm{Fe}(\mathrm{II})$ transforms into $\mathrm{Fe}(\mathrm{III})$, which does not lead to the generation of hydroxyl radicals (Formula 1, below) [92]. If the redox-inactive $\mathrm{Fe}(\mathrm{III})$ is not reduced to redox-active $\mathrm{Fe}$ (II) again, the $\mathrm{Fe}$ (II) that has reacted once with hydrogen peroxide through the Fenton reaction will not be able to repeatedly generate hydroxyl radicals. This leads to only mild oxidative damage to nDNA. The nucleus is widely recognized to possess an efficient repair system for oxidative DNA damage. This system can effectively repair mild DNA damage $[93,94]$. Kulkarni and Wilson have reported that although human cells are subjected to a daily average of approximately one million DNA lesions, under physiological conditions, these lesions are repaired every day by the DNA repair system [95].

Conversely, Imlay et al. have reported that considerable oxidative damage to DNA through the Fenton reaction requires the presence of either a constant source of reducing equivalents or sufficient amounts of reducing compounds in order to repeatedly reduce $\mathrm{Fe}$ (III) into the redox-active $\mathrm{Fe}$ (II) [96, 97]. Chakrabarti et al. have reported the presence of substantial oxidative DNA damage by hydroxyl radicals in the presence of adriamycin-bound $\mathrm{Fe}(\mathrm{III})$, hydrogen peroxide, and ascorbate [98]. Adriamycin interacts with DNA by intercalating between DNA bases [99]. Chakrabarti et al. have reported that ascorbate present in sufficient amounts can repeatedly reduce adriamycin-bound $\mathrm{Fe}(\mathrm{III})$ to $\mathrm{Fe}(\mathrm{II})$, which results in repeated production of hydroxyl radicals through the Fenton reaction [98].

Al has been reported to promote Fe-mediated oxidation [28, 29, 31, 32]. Recently, Exley [24] and Lopez et al. $[26,100]$ have reported that $\mathrm{Al}^{3+}$ binds to the superoxide anion radical $\left(\mathrm{O}_{2}^{-\bullet}\right.$, superoxide) to form the Al superoxide semi-reduced 
radical ion $\left(\mathrm{AlO}_{2}{ }^{2+} \bullet\right.$, Al-superoxide complex $)$ under physiological conditions (Formula 2, below). The Al-superoxide complex can reduce $\mathrm{Fe}$ (III) to $\mathrm{Fe}(\mathrm{II})$ (Formula 3, below). The newly formed Fe(II) was reported to be capable of generating hydroxyl radicals again, thus implicating the occurrence of a cyclic reaction in this biological oxidation pathway.

Based on the results presented in these reports [24, 26, 100], it appears that the $\mathrm{Al}$ and Fe colocalized in the nuclei of nerve cells in the AD brain may catalyze the cyclic reaction leading to the generation of hydroxyl radicals. These hydroxyl radicals may then lead to marked oxidative damage to nDNA in the presence of hydrogen peroxide and superoxide.

$$
\begin{aligned}
& \mathrm{Fe}^{2+}+\mathrm{H}_{2} \mathrm{O}_{2} \rightarrow \mathrm{Fe}^{3+}+\mathrm{OH} \bullet+\mathrm{OH}^{-} \quad(\text { Formula } 1) \\
& \mathrm{Al}^{3+}+\mathrm{O}_{2-} \bullet \leftrightarrow \mathrm{AlO}_{2}^{2+} \bullet \quad(\text { Formula } 2) \\
& \mathrm{Fe}^{3+}+\mathrm{AlO}_{2}{ }^{2+} \bullet \rightarrow \mathrm{Fe}^{2+}+\mathrm{Al}^{3+}+\mathrm{O}_{2} \quad(\text { Formula } 3)
\end{aligned}
$$

The human brain is a highly aerobic organ; although the brain accounts for only $2 \%$ of the body weight, it consumes as much as $20 \%$ of the oxygen in the entire body [101-103]. The oxygen in the brain is largely used by neurons to supply the energy to maintain ion gradients across the plasma membrane, which are essential for the generation of action potentials. This energy requirement of neurons is driven by mitochondrial oxidative phosphorylation. Notably, approximately $2 \%$ of the oxygen consumed in mitochondria is converted into ROS such as superoxide and hydrogen peroxide [101, 104, 105]. Because superoxide and hydrogen peroxide can cross cell membranes through anion channels [106-109] and aquaporin water channels, respectively [108-110], large amounts of the superoxide and hydrogen peroxide generated in mitochondria diffuse into the cytoplasm and the nuclei of nerve cells.

In the young adult brain, hydrogen peroxide is efficiently detoxified by glutathione peroxidase and catalase in the cytoplasm [111]. Superoxide is also actively catalyzed by superoxide dismutase into hydrogen peroxide and oxygen [112]. In contrast, in the aged brain, the amounts of ROS generated in mitochondria increase markedly because of the mitochondrial dysfunction that occurs with aging [113-115]. Venkateshappa et al. have reported that antioxidant enzyme activities decrease considerably in the human hippocampus and frontal cortex with increasing age [116]. Therefore, neurons in the aged brain appear to be particularly vulnerable to ROS when compared with neurons in the young adult brain $[117,118]$.

Another key previous finding is that metals that bind to DNA or DNA-binding proteins inhibit the repair of oxidatively damaged DNA [85, 119-121]. These metals, including $\mathrm{Fe}$ and $\mathrm{Al}$, were reported to impair the DNA glycosidase activity required for the repair of DNA base excision $[119,120]$. Hegde et al. also reported that the Fe that bound to DNA inhibited the activities of DNA-repair enzymes by both oxidizing these enzymes and forming stable complexes with the enzymes [121]. These stable complexes were reported to interfere with the scanning and detection of DNA damage. Therefore, it is probable that the $\mathrm{Fe}$ and $\mathrm{Al}$ colocalized in the nuclei of nerve cells not only cause oxidative damage to nDNA but also concurrently inhibit the repair of oxidatively damaged nDNA [84, 121, 122].

An imbalance resulting from the increase in oxidative nDNA damage and the decrease in DNA repair activities might lead to the accumulation of unrepaired damaged DNA with increasing age [95, 123]. Lovell and Markesbery [38] and Coppedè and Migliore [124] have reported that accumulation of DNA damage is one of the earliest detectable events during the progression from healthy aging to dementia. Accumulation of nDNA damage in neurons has been considered to be a major factor in $\mathrm{AD}$ development [125]. The increased amount of genome damage might result in RNA and protein damage, giving rise to misfolding and aggregation of abnormal protein components $[126,127]$. Toxic protein aggregates have been reported as potential contributory factors to various neurodegenerative diseases. These proteins include amyloid- $\beta$ in $\mathrm{AD}[3,8]$, tau in frontotemporal dementia [128], and $\alpha$-synuclein in Parkinson's disease [129]. Consequently, accumulation of nDNA damage in neurons might induce neurodegenerative pathology and, ultimately, neuron death.

In conclusion, we used SEM-EDS analysis to demonstrate the colocalization of $\mathrm{Al}$ and $\mathrm{Fe}$ in the nuclei of nerve cells in brains from patients with AD. The highest levels of both $\mathrm{Al}$ and Fe were measured in the nucleoli of nerve cells from AD brains. The colocalization of $\mathrm{Al}$ and $\mathrm{Fe}$ was also demonstrated in heterochromatin and euchromatin in neuronal nuclei from $\mathrm{AD}$ brains. $\mathrm{Al}$ and $\mathrm{Fe}$ levels in neuronal nuclei were markedly higher in $\mathrm{AD}$ brains than in agematched control brains. We hypothesize that the $\mathrm{Al}$ and Fe colocalized in the nuclei of nerve cells might 
play a pivotal role in neuron degeneration and $\mathrm{AD}$ pathogenesis by inducing oxidative nDNA damage and, concomitantly, inhibiting the repair of oxidatively damaged nDNA.

\section{ACKNOWLEDGMENTS}

The authors thank Dr. Koichi Kobayashi, Dr. Hisao Nagai, and Dr. Tadashi Shimamura for valuable discussion and technical assistance. The authors would like to acknowledge the Department of Pathology at the University of Tokyo and the Department of Pathology at the Nihon University School of Medicine for the provision of brain tissues used in this study. The authors thank the Micro Analysis Laboratory of the University of Tokyo for the PIXE assays of the samples.

Authors' disclosures available online (https:// www.j-alz.com/manuscript-disclosures/17-1108r1).

\section{REFERENCES}

[1] Smith MA, Rottkamp CA, Nunomura A, Raina AK, Perry $\mathrm{G}$ (2000) Oxidative stress in Alzheimer's disease. Biochim Biophys Acta 1502, 139-144.

[2] Kawahara M (2005) Effects of aluminum on the nervous system and its possible link with neurodegenerative diseases. J Alzheimers Dis 8, 171-182.

[3] Masters CL, Selkoe DJ (2012) Biochemistry of amyloid $\beta$ protein and amyloid deposits in Alzheimer disease. Cold Spring Harb Perspect Med 2, a006262.

[4] Walton JR (2014) Chronic aluminum intake causes Alzheimer's disease: Applying Sir Austin Bradford Hill's causality criteria. J Alzheimers Dis 40, 765-838.

[5] Hebert LE, Scherr PA, Beckett LA, Albert MS, Pilgrim DM, Chown MJ, Funkenstein HH, Evans DA (1995) Agespecific incidence of Alzheimer's disease in a community population. JAMA 273, 1354-1359.

[6] Evans DA, Funkenstein HH, Albert MS, Scherr PA, Cook NR, Chown MJ, Hebert LE, Hennekens CH, Taylor JO (1989) Prevalence of Alzheimer's disease in a community population of older persons. Higher than previously reported. JAMA 262, 2551-2556.

[7] Keller JN (2006) Age-related neuropathology, cognitive decline, and Alzheimer's disease. Ageing Res Rev 5, 1-13.

[8] Yankner BA, Lu T, Loerch P (2008) The aging brain. Annu Rev Pathol 3, 41-66.

[9] Khan A, Dobson JP, Exley C (2006) Redox cycling of iron by Abeta42. Free Radic Biol Med 40, 557-569.

[10] Castellani RJ, Moreira PI, Liu G, Dobson J, Perry G, Smith MA, Zhu X (2007) Iron: The redox-active center of oxidative stress in Alzheimer disease. Neurochem Res 32, 1640-1645.

[11] Moreira PI, Nunomura A, Nakamura M, Takeda A, Shenk JC, Aliev G, Smith MA, Perry G (2008) Nucleic acid oxidation in Alzheimer disease. Free Radic Biol Med 44, 1493-1505.
[12] Gwon AR, Park JS, Arumugam TV, Kwon YK, Chan SL, Kim SH, Baik SH, Yang S, Yun YK, Choi Y, Kim S, Tang SC, Hyun DH, Cheng A, Dann CE 3rd, Bernier M, Lee J, Markesbery WR, Mattson MP, Jo DG (2012) Oxidative lipid modification of nicastrin enhances amyloidogenic $\gamma$ secretase activity in Alzheimer's disease. Aging Cell 11, 559-568.

[13] Gella A, Durany N (2009) Oxidative stress in Alzheimer disease. Cell Adh Migr 3, 88-93.

[14] Zecca L, Youdim MBH, Riederer P, Connor JR, Crichton RR (2004) Iron, brain ageing and neurodegenerative disorders. Nat Rev Neurosci 5, 863-873.

[15] Smith MA, Zhu X, Tabaton M, Liu G, McKeel DW Jr, Cohen ML, Wang X, Siedlak SL, Dwyer BE, Hayashi T, Nakamura M, Nunomura A, Perry G (2010) Increased iron and free radical generation in preclinical Alzheimer disease and mild cognitive impairment. J Alzheimers Dis 19, 363-372.

[16] Oakley AE, Collingwood JF, Dobson J, Love G., Perrott HR, Edwardson JA, Elstner M, Morris CM (2007) Individual dopaminergic neurons show raised iron levels in Parkinson disease. Neurology 68, 1820-1825.

[17] Jurgens CK, Jasinschi R, Ekin A, Witjes-Ané MN, Middelkoop H, van der Grond J, Roos RA (2010) MRI T2 Hypointensities in basal ganglia of premanifest Huntington's disease. PLoS Curr 2, pii: RRN1173.

[18] Langkammer C, Enzinger C, Quasthoff S, Grafenauer P, Soellinger M, Fazekas F, Ropele S (2010) Mapping of iron deposition in conjunction with assessment of nerve fiber tract integrity in amyotrophic lateral sclerosis. J Magn Reson Imaging 31, 1339-1345.

[19] Halliwell B, Gutteridge JM (1984) Oxygen toxicity, oxygen radicals, transition metals and disease. Biochem J 219, 1-14.

[20] Deibel MA, Ehmann WD, Markesbery WR (1996) Copper, iron, and zinc imbalances in severely degenerated brain regions in Alzheimer's disease: Possible relation to oxidative stress. J Neurol Sci 143, 137-142.

[21] Magaki S, Raghavan R, Mueller C, Oberg KC, Vinters HV, Kirsch WM (2007) Iron, copper, and iron regulatory protein 2 in Alzheimer's disease and related dementias. Neurosci Lett 418, 72-76.

[22] Honda K, Casadesus G, Petersen RB, Perry G, Smith MA (2004) Oxidative stress and redox-active iron in Alzheimer's disease. Ann N Y Acad Sci 1012, 179-182.

[23] Gutteridge JM, Quinlan GJ, Clark I, Halliwell B (1985) Aluminium salts accelerate peroxidation of membrane lipids stimulated by iron (II) salts. Biochim Biophys Acta 835, 441-447.

[24] Exley C (2004) The pro-oxidant activity of aluminum. Free Radic Biol Med 36, 380-387.

[25] Exley C (2012) The coordination chemistry of aluminium in neurodegenerative disease. Coordin Chem Rev 256, 2142-2146.

[26] Ruipérez F, Mujika JI, Ugalde JM, Exley C, Lopez X (2012) Pro-oxidant activity of aluminum: Promoting the Fenton reaction by reducing $\mathrm{Fe}(\mathrm{III})$ to $\mathrm{Fe}(\mathrm{II}) . J$ Inorg Biochem 117, 118-123.

[27] Ohyashiki T, Karino T, Matsui K (1993) Stimulation of $\mathrm{Fe}(2+)$-induced lipid peroxidation in phosphatidylcholine liposomes by aluminium ions at physiological $\mathrm{pH}$. Biochim Biophys Acta 1170, 182-188.

[28] Yoshino M, Ito M, Haneda M, Tsubouchi R, Murakami K (1999) Prooxidant action of aluminum ion-stimulation of 
iron-mediated lipid peroxidation by aluminum. Biometals 12, 237-240.

[29] Kaneko N, Yasui H, Takada J, Suzuki K, Sakurai H (2004) Orally administrated aluminum-maltolate complex enhances oxidative stress in the organs of mice. $J$ Inorg Biochem 98, 2022-2031.

[30] Rui D, Yongjian Y (2010) Aluminum chloride induced oxidative damage on cells derived from hippocampus and cortex of ICR mice. Brain Res 1324, 96-102.

[31] Xie CX, Mattson MP, Lovell MA, Yokel RA (1996) Intraneuronal aluminum potentiates iron-induced oxidative stress in cultured rat hippocampal neurons. Brain Res 743, 271-277.

[32] Alexandrov PN, Zhao Y, Pogue AI, Tarr MA, Kruck TP, Percy ME, Cui JG, Lukiw WJ (2005) Synergistic effects of iron and aluminum on stress-related gene expression in primary human neural cells. J Alzheimers Dis 8, 117-127.

[33] McDermott JR, Smith AI, Iqbal K, Wisniewski HM (1979) Brain aluminum in aging and Alzheimer disease. Neurology 29, 809-814.

[34] Markesbery WR, Ehmann WD, Hossain TI, Alauddin M, Goodin DT (1981) Instrumental neutron activation analysis of brain aluminum in Alzheimer disease and aging. Ann Neurol 10, 511-516.

[35] Shimizu H, Mori T, Koyama M, Sekiya M, Ooami H (1994) A correlative study of the aluminum content and aging changes of the brain in non-demented elderly subjects. Jpn J Geriatrics (Tokyo) 31, 950-960.

[36] Virk SA, Eslick GD (2015) Aluminum levels in brain, serum, and cerebrospinal fluid are higher in Alzheimer's disease cases than in controls: A Series of meta-analyses. J Alzheimers Dis 47, 629-638.

[37] Gabbita SP, Lovell MA, Markesbery WR (1998) Increased nuclear DNA oxidation in the brain in Alzheimer's disease. J Neurochem 71, 2034-2040

[38] Lovell MA, Markesbery WR (2007) Oxidative DNA damage in mild cognitive impairment and late-stage Alzheimer's disease. Nucleic Acids Res 35, 7497-7504.

[39] Santos RX, Correia SC, Zhu X, Lee HG, Petersen RB, Nunomura A, Smith MA, Perry G, Moreira PI (2012) Nuclear and mitochondrial DNA oxidation in Alzheimer's disease. Free Radic Res 46, 565-576.

[40] Gebicki JM, Bielski BH (1981) Comparison of the capacities of the perhydroxyl and superoxide radicals to initiate chain oxidation of linoleic acid. J Am Chem Soc 103, 7020-7022.

[41] Halliwell B, Gutteridge JM (1992) Biologically relevant metal ion-dependent hydroxyl radical generation. An update. FEBS Lett 307, 108-112.

[42] Altman SA, Zastawny TH, Randers-Eichhorn L, Cacciuttolo MA, Akman SA, Dizdaroglu M, Rao G (1995) Formation of DNA-protein cross-links in cultured mammalian cells upon treatment with iron ions. Free Radic Biol Med 19, 897-902.

[43] Jomova K, Vondrakova D, Lawson M, Valko M (2010) Metals, oxidative stress and neurodegenerative disorders. Mol Cell Biochem 345, 91-104.

[44] Tretyakova NY, Groehler A 4th, Ji S (2015) DNA-protein cross-links: Formation, structural identities, and biological outcomes. Acc Chem Res 48, 1631-1644.

[45] Prestwich EG, Roy MD, Rego J, Kelley SO (2005) Oxidative DNA strand scission induced by peptides. Chem Biol 12, 695-710.

[46] Mahon KP Jr, Roy MD Carreon JR, Prestwich EG, Rouge JL, Shin S, Kelley SO (2006) Tunable DNA cleavage by intercalating peptidoconjugates. Chembiochem 7, 766773.

[47] Pryor WA (1986) Oxy-radicals and related species: Their formation, lifetimes, and reactions. Annu Rev Physiol 48, 657-667.

[48] Sies H (1993) Strategies of antioxidant defense. Eur J Biochem 215, 213-219.

[49] Hayes JJ, Clark DJ, Wolffe AP (1991) Histone contributions to the structure of DNA in the nucleosome. Proc Natl Acad Sci U S A 88, 6829-6833.

[50] Pruss D, Wolffe AP (1993) Histone-DNA contacts in a nucleosome core containing a Xenopus 5S rRNA gene. Biochemistry 32, 6810-6814.

[51] Hayes JJ, Pruss D, Wolffe AP (1994) Contacts of the globular domain of histone $\mathrm{H} 5$ and core histones with DNA in a "chromatosome". Proc Natl Acad Sci U SA 91, 7817-7821.

[52] Bharath MM, Chandra NR, Rao MR (2003) Molecular modeling of the chromatosome particle. Nucleic Acids Res. 31, 4264-4274.

[53] Honda K, Smith MA, Zhu X, Baus D, Merrick WC, Tartakoff AM, Hattier T, Harris PL, Siedlak SL, Fujioka H, Liu Q, Moreira PI, Miller FP, Nunomura A, Shimohama S, Perry G (2005) Ribosomal RNA in Alzheimer disease is oxidized by bound redox-active iron. J Biol Chem $\mathbf{2 8 0}$, 20978-20986.

[54] Quintana C, Bellefqih S, Laval JY, Guerquin-Kern JL, Wu TD, Avila J, Ferrer I, Arranz R, Patiño C (2006) Study of the localization of iron, ferritin, and hemosiderin in Alzheimer's disease hippocampus by analytical microscopy at the subcellular level. J Struct Biol 153, 42-54.

[55] Connor JR, Menzies SL, St Martin SM, Mufson EJ (1992) A histochemical study of iron, transferrin, and ferritin in Alzheimer's diseased brains. J Neurosci Res 31, 75-83.

[56] Connor JR, Menzies SL, St Martin SM, Mufson EJ (1990) Cellular distribution of transferrin, ferritin, and iron in normal and aged human brains. J Neurosci Res 27, 595-611.

[57] Lukiw WJ, Kruck TP, Crapper McLachlan DR (1989) Aluminium and the nucleus of nerve cells. Lancet 1, 781 .

[58] Walton JR (2006) Aluminum in hippocampal neurons from humans with Alzheimer's disease. Neurotoxicology 27, 385-394.

[59] Yumoto S, Horino Y, Mokuno Y, Kakimi S, Fujii K (1996) Microprobe PIXE analysis of aluminum in the brains of patients with Alzheimer's disease. Nucl Instrum Meth B 109/110, 362-367.

[60] Yumoto S, Maekawa C, Homma Y (1995) SIMS analysis of aluminium in the brains of patients with Alzheimer's disease. In Secondary Ion Mass Spectrometry SIMS X, Benninghoven A, Hagenhoff B, Werner HW, eds. John Wikey \& Sons, New York, pp. 819-821.

[61] Yumoto S, Kakimi S, Matsushima H, Ishikawa A, Homma Y (1998) Demonstration of aluminium in the brain of patients with Alzheimer's disease. In Progress in Alzheimer's and Parkinson's diseases, Fisher A, Hanin I, Yoshida M, eds. Plenum Press, New York, pp. 293-300.

[62] Yumoto S, Horino Y, Mokuno Y. Fujii K, Kakimi S, Mizutani T, Matsushima H, Ishikawa A (1996) Microprobe PIXE analysis and EDX analysis on the brain of patients with Alzheimer's disease. Int J PIXE 6, 193-204.

[63] Yumoto S, Kakimi S, Ohsaki S, Ishikawa A (2009) Demonstration of aluminum in amyloid fibers in the core of senile plaques in the brains of patients with Alzheimer's disease. J Inorg Biochem 103, 1579-1584. 
[64] Bearden JA (1967) X-ray wavelengths. Rev Mod Phys 39, 78-124.

[65] Johansson SAE, Campbell JL (1988) PIXE: A Novel Technique for Elemental Analysis, John Wiley and Sons, Chichester.

[66] Wang J, Xiong S, Xie C, Markesbery WR, Lovell MA (2005) Increased oxidative damage in nuclear and mitochondrial DNA in Alzheimer's disease. J Neurochem 93, 953-962.

[67] Welch BL (1938) The significance of the difference between two means when the population variances are unequal. Biometrika 29, 350-362.

[68] Kametani K (2002) Detection of aluminium by energy dispersive X-ray microanalysis at high accelerating voltages with semi-thin sections of biological sample. J Electron Microsc (Tokyo) 51, 265-274.

[69] Kojima T, Saito K, Kakimi S (1970) An Electron Microscopic Atlas of Neurons, University of Tokyo Press, Tokyo.

[70] Sumpter PQ, Mann DM, Davies CA, Yates PO, Snowden JS, Neary D (1986) An ultrastructural analysis of the effects of accumulation of neurofibrillary tangle in pyramidal neurons of the cerebral cortex in Alzheimer's disease. Neuropathol Appl Neurobiol 12, 305-319.

[71] Walton JR (2010) Evidence for participation of aluminum in neurofibrillary tangle formation and growth in Alzheimer's disease. J Alzheimers Dis 22, 65-72.

[72] Smith MA, Harris PLR, Sayre LM, Perry G (1997) Iron accumulation in Alzheimer disease is a source of redoxgenerated free radicals. Proc Natl Acad Sci U S A 94, 9866-9868.

[73] Raha AA, Vaishnav RA, Friedland R, Bomford A, Raha-Chowdhury R (2013) The systemic iron-regulatory proteins hepcidin and ferroportin are reduced in the brain in Alzheimer's disease. Acta Neuropathol Commun 1, 55.

[74] Hofer T, Perry G (2016) Nucleic acid oxidative damage in Alzheimer's disease-explained by the hepcidin-ferroportin neuronal iron overload hypothesis? J Trace Elem Med Biol 38, 1-9.

[75] Yumoto S, Nagai H, Imamura M, Matsuzaki H, Hayashi K, Masuda A, Kumazawa H, Ohashi H, Kobayashi K (1997) ${ }^{26} \mathrm{Al}$ uptake and accumulation in the rat brain. Nucl Instrum Meth B 123, 279-282.

[76] Wolschin F, Wienkoop S, Weckwerth W (2005) Enrichment of phosphorylated proteins and peptides from complex mixtures using metal oxide/hydroxide affinity chromatography (MOAC). Proteomics 5, 4389-4397.

[77] Mauca D, Russo N, Toscano M, Grand A (2006) On the interaction of bare and hydrated aluminum ion with nucleic acid bases (U, T, C, A, G) and monophosphate nucleotides (UMP, dTMP, dCMP, dAMP, dGMP). J Phys Chem B 110, 8815-882.

[78] Pogue AI, Lukiw WJ (2014) The mobilization of aluminum into the biosphere. Front Neurol 5, 262.

[79] Martin RB (1992) Aluminium speciation in biology. Ciba Found Symp 169, 5-25.

[80] Lukiw WJ, Krishnan B, Wong L, Kruck TP, Bergeron C, Crapper McLachlan DR (1992) Nuclear compartmentalization of aluminum in Alzheimer's disease (AD). Neurobiol Aging 13, 115-121.

[81] Lukiw WJ (2010) Evidence supporting a biological role for aluminum in chromatin compaction and epigenetics. J Inorg Biochem 104, 1010-1012.

[82] Llorente AR, Del Castillo P, Stockert JC (1989) Aluminium binding to chromatin DNA as revealed by formation of fluorescent complexes with 8hydroxyquinoline and other ligands. J Microsc 155, 227-230.

[83] Stensballe A, Jensen ON (2004) Phosphoric acid enhances the performance of $\mathrm{Fe}(\mathrm{III})$ affinity chromatography and matrix-assisted laser desorption/ionization tandem mass spectrometry for recovery, detection and sequencing of phosphopeptides. Rapid Commun Mass Spectrom 18, 1721-1730.

[84] Hegde ML, Hegde PM, Rao KS, Mitra S (2011) Oxidative genome damage and its repair in neurodegenerative diseases: Function of transition metals as a double-edged sword. J Alzheimers Dis 24(Suppl 2), 183-198.

[85] Li H, Swiercz R, Englander EW (2009) Elevated metals compromise repair of oxidative DNA damage via the base excision repair pathway: Implications of pathologic iron overload in the brain on integrity of neuronal DNA. J Neurochem 110, 1774-1783.

[86] Smith MA, Wehr K, Harris PL, Siedlak SL, Connor JR, Perry G (1998) Abnormal localization of iron regulatory protein in Alzheimer's disease. Brain Res 788, 232-236.

[87] Webb J, Multani JS, Saltman P, Beach NA, Gray HB (1973) Spectroscopic and magnetic studies of iron (III) phosvitins. Biochemistry 12, 1797-1802.

[88] Yamamoto A, Shin RW, Hasegawa K, Naiki H, Sato H, Yoshimasu F, Kitamoto T (2002) Iron (III) induces aggregation of hyperphosphorylated tau and its reduction to iron (II) reverses the aggregation: Implications in the formation of neurofibrillary tangles of Alzheimer's disease. J Neurochem 82, 1137-1147.

[89] Goedert M, Wischik CM, Crowther RA, Walker JE, Klug A (1988) Cloning and sequencing of the cDNA encoding a core protein of the paired helical filament of Alzheimer disease: Identification as the microtubule-associated protein tau. Proc Natl Acad Sci U S A 85, 4051-4055.

[90] Wilhelm M, Gaillard S, Rakov V, Funk F (2014) The iron-based phosphate binder PA21 has potent phosphate binding capacity and minimal iron release across a physiological pH range in vitro. Clin Nephrol 81, 251-258.

[91] Henle ES, Han Z, Tang N, Rai P, Luo Y, Linn S (1999) Sequence-specific DNA cleavage by $\mathrm{Fe}^{2+}$-mediated fenton reactions has possible biological implications. J Biol Chem 274, 962-971.

[92] Winterbourn CC (1995) Toxicity of iron and hydrogen peroxide: The Fenton reaction. Toxicol Lett 82-83, 969974.

[93] Wood RD (1996) DNA repair in eukaryotes. Аnпи Rev Biochem 65, 135-167.

[94] Caldecott KW (2003) DNA single-strand break repair and spinocerebellar ataxia. Cell 112, 7-10.

[95] Kulkarni A, Wilson DM 3rd (2008) The involvement of DNA-damage and repair defects in neurological dysfunction. Am J Hum Genet 82, 539-566.

[96] Imlay JA, Linn S (1988) DNA damage and oxygen radical toxicity. Science 240, 1302-1309.

[97] Woodmansee AN, Imlay JA (2002) Reduced flavins promote oxidative DNA damage in non-respiring Escherichia coli by delivering electrons to intracellular free iron. J Biol Chem 277, 34055-34066.

[98] Chakrabarti S, Mahmood A, Kassis AI, Bump EA, Jones AG, Makrigiorgos GM (1996) Generation of hydroxyl radicals by nucleohistone-bound metal-adriamycin complexes. Free Radic Res 25, 207-220.

[99] Momparler RL, Karon M, Siegel SE, Avila F (1976) Effect of adriamycin on DNA, RNA, and protein synthesis 
in cell-free systems and intact cells. Cancer Res 36, 2891-2895.

[100] Mujika JI, Ruipérez F, Infante I, Ugalde JM, Exley C, Lopez X (2011) Pro-oxidant activity of aluminum: Stabilization of the aluminum superoxide radical ion. $J$ Phys Chem A 115, 6717-6723.

[101] Leonard WR, Snodgrass JJ, Robertson ML (2007) Effects of brain evolution on human nutrition and metabolism. Annu Rev Nutr 27, 311-327.

[102] Moreira PI, Carvalho C, Zhu X, Smith MA, Perry G (2010) Mitochondrial dysfunction is a trigger of Alzheimer's disease pathophysiology. Biochim Biophys Acta 1802, 2-10.

[103] Moreira PI, Zhu X, Wang X, Lee HG, Nunomura A, Petersen RB, Perry G, Smith MA (2010) Mitochondria: A therapeutic target in neurodegeneration. Biochim Biophys Acta 1802, 212-220.

[104] Chance B, Sies H, Boveris A (1979) Hydroperoxide metabolism in mammalian organs. Physiol Rev 59, 527605.

[105] Santos RX, Correia SC, Wang X, Perry G, Smith MA, Moreira PI, Zhu X (2010) Alzheimer's disease: Diverse aspects of mitochondrial malfunctioning. Int J Clin Exp Pathol 3, 570-581.

[106] Hoffmann EK (2000) Intracellular signalling involved in volume regulatory decrease. Cell Physiol Biochem 10, 273-288.

[107] Franco-Obregón A, Wang HW, Clapham DE (2000) Distinct ion channel classes are expressed on the outer nuclear envelope of T- and B-lymphocyte cell lines. Biophys J 79, 202-214.

[108] Hawkins BJ, Madesh M, Kirkpatrick CJ, Fisher AB (2007) Superoxide flux in endothelial cells via the chloride channel-3 mediates intracellular signaling. Mol Biol Cell 18, 2002-2012.

[109] Fisher AB (2009) Redox signaling across cell membranes. Antioxid Redox Signal 11, 1349-1356.

[110] Bienert GP, Møller AL, Kristiansen KA, Schulz A, Møller IM, Schjoerring JK, Jahn TP (2007) Specific aquaporins facilitate the diffusion of hydrogen peroxide across membranes. J Biol Chem 282, 1183-1192.

[111] Takizawa S, Matsushima K, Shinohara Y, Ogawa S, Komatsu N, Utsunomiya H, Watanabe K (1994) Immunohistochemical localization of glutathione peroxidase in infarcted human brain. J Neurol Sci 122, 66-73.

[112] Barone E, Cenini G, Di Domenico F, Noel T, Wang C, Perluigi M, St Clair DK, Butterfield DA (2015) Basal brain oxidative and nitrative stress levels are finely regulated by the interplay between superoxide dismutase 2 and p53. J Neurosci Res 93, 1728-1739.

[113] Petrosillo G, Matera M, Casanova G, Ruggiero FM, Paradies G (2008) Mitochondrial dysfunction in rat brain with aging involvement of complex I, reactive oxygen species and cardiolipin. Neurochem Int 53, 126-131.

[114] Lezi E, Swerdlow RH (2012) Mitochondria in neurodegeneration. Adv Exp Med Biol 942, 269-286.

[115] Johri A, Beal MF (2012) Mitochondrial dysfunction in neurodegenerative diseases. J Pharmacol Exp Ther 342, 619-630.
[116] Venkateshappa C, Harish G, Mahadevan A, Srinivas Bharath MM, Shankar SK (2012) Elevated oxidative stress and decreased antioxidant function in the human hippocampus and frontal cortex with increasing age: Implications for neurodegeneration in Alzheimer's disease. Neurochem Res 37, 1601-1614.

[117] Mancuso M, Coppedè F, Migliore L, Siciliano G, Murri L (2006) Mitochondrial dysfunction, oxidative stress and neurodegeneration. J Alzheimers Dis 10, 59-73.

[118] Barzilai A (2007) The contribution of the DNA damage response to neuronal viability. Antioxid Redox Signal 9, 211-218.

[119] Lankoff A, Banasik A, Duma A, Ochniak E, Lisowska H, Kuszewski T, Góźdź S, Wojcik A (2006) A comet assay study reveals that aluminium induces DNA damage and inhibits the repair of radiation-induced lesions in human peripheral blood lymphocytes. Toxicol Lett 161, 27-36.

[120] Grin IR, Konorovsky PG, Nevinsky GA, Zharkov DO (2009) Heavy metal ions affect the activity of DNA glycosylases of the fpg family. Biochemistry (Mosc) 74, 1253-1259.

[121] Hegde ML, Hegde PM, Holthauzen LMF, Hazra TK, Rao KSJ, Mitra S (2010) Specific inhibition of NEIL-initiated repair of oxidized base damage in human genome by copper and iron: Potential etiological linkage to neurodegenerative diseases. J Biol Chem 285, 28812-28825.

[122] Coppedè F., Migliore L (2009) DNA damage and repair in Alzheimer's disease. Curr Alzheimer Res 6, 36-47.

[123] Hegde ML, Izumi T, Mitra S (2012) Oxidized base damage and single-strand break repair in mammalian genomes: Role of disordered regions and posttranslational modifications in early enzymes. Prog Mol Biol Transl Sci 110, 123-153.

[124] Coppedè F, Migliore L (2015) DNA damage in neurodegenerative diseases. Mutat Res 776, 84-97.

[125] Brasnjevic I, Hof PR, Steinbusch HW, Schmitz C (2008) Accumulation of nuclear DNA damage or neuron loss: Molecular basis for a new approach to understanding selective neuronal vulnerability in neurodegenerative diseases. DNA Repair (Amst) 7, 1087-1097.

[126] Mitra J, Guerrero EN, Hegde PM, Wang H, Boldogh I, Rao KS, Mitra S, Hegde ML (2014) New perspectives on oxidized genome damage and repair inhibition by prooxidant metals in neurological diseases. Biomolecules $\mathbf{4}$, 678-703.

[127] Pogue AI, Lukiw WJ (2016) Aluminum, the genetic apparatus of the human CNS and Alzheimer's disease (AD). Morphologie 100, 56-64.

[128] Ghetti B, Oblak A, Boeve BF, Johnson KA, Dickerson BC, Goedert M (2015) Invited review: Frontotemporal dementia caused by microtubule-associated protein tau gene (MAPT) mutations: A chameleon for neuropathology and neuroimaging. Neuropathol Appl Neurobiol 41, 24-46.

[129] Prasad K, Beach TG, Hedreen J, Richfield EK (2012) Critical role of truncated $\alpha$-synuclein and aggregates in Parkinson's disease and incidental Lewy body disease. Brain Pathol 22, 811-825. 